DOI: https://doi.org/10.36477/tourismhospcee-2-6

УДК 331.1

Сагайдак-Никитюк Р. В.

доктор фармацевтичних наук, професор, професор кафедри менеджменту і публічного адміністрування Національного фармацевтичного університету

ORCID: https://orcid.org/0000-0002-9337-7741

Барнатович C. B.

кандидат фармацевтичних наук, доцент, доцент кафедри технології ліків, організації та економіки фармації Д3 «Луганський державний медичний університет» ORCID: https://orcid.org/0000-0003-0752-3544

Sahaidak-Nikitiuk Rita National University of Pharmacy

Barnatovych Svetlana

PP «Lugansk State Medical University»

\title{
ДОСЛІДЖЕННЯ ПРОФЕСІЙНИХ ОБОВ'ЯЗКІВ КАТЕГОРІЙНИХ МЕНЕДЖЕРІВ ФАРМАЦЕВТИЧНИХ ОРГАНІЗАЦІЙ
}

\author{
RESEARCH OF PROFESSIONAL RESPONSIBILITIES \\ OF CATEGORY MANAGERS OF PHARMACEUTICAL ORGANIZATIONS
}

Досліджено фармацевтичний ринок Украӥни та його особливості. Визначено доиільність впровадження посади категоріального менеджера. Визначено місце категорійного менеджера в каналі товароруху. Сформульовано завдання категорійного менеджера фармацевтичних організаџій. Запропоновано професійні обов'язки категорійних менеджерів фармацевтичних організацій, поділені на загальні обов 'язки, обов 'язки у сфері маркетингу, обов'язки у сфері закупівлі, обов'язки у сфері асортименту, обов'язки у сфері ціноутворення, обов 'язки у сфері взаємодії з підлеглими, обов'язки у сфері планування і звітності, обов 'язки у сфері аналізу ефективності продажів по категоріях фармачевтичних товарів. Вивчено та сформульовано права та відповідальність категорійного менеджера з урахуванням специфіки фармацевтичних організацій.

Ключові слова: категорійний менеджер, фармацеевтчна організація, посадові обов'язки, лікарський засіб, права, відповідальність.

Исследован фармацевтический рынок Украины и его особенности. Определена целесообразность внедрения должности категориального менеджера. Определено место категорийного менеджера в канале товародвижения. Сформулированы задачи категорийного менеджера фармацевтических организаций. Предложены профессиональнье обязанности категорийных менеджеров фармацевтических организаций, которые разделень на общие обязанности, обязанности в сфере маркетинга, обязанности в сфере закуп$\kappa и$, обязанности в области ассортимента, обязанности в сфере ценообразования, обязанности в сфере взаимодействия с подчиненныли, обязанности в сфере планирования и отчетности, обязанности в сфере анализа эффективности продаж по категориям фармацевтических товаров. Изучень и сформулированы права и ответственность категорийного менеджера с учетом специифики фармачевтических организаций.

Ключевые слова: категорийный менеджер, фармачевтическая организащия, долэностные обязанности, лекарственное средство, права, ответственность.

The pharmaceutical market of Ukraine and its features are studied. 10,776 medicines are registered in Ukraine. Pharmaceutical companies of Ukraine produce drugs of almost all dosage forms of all pharmacotherapeutic groups. A characteristic feature of a market economy is the saturation of the pharmaceutical market with a variety of goods. The expediency of introducing the position of a categorical manager has been determined. The place of the category manager in the channel of goods movement is defined. The tasks of the category manager of pharmaceutical organizations are formulated. The task of a category manager is to manage a certain category of goods manager. The professional responsibilities of category managers of pharmaceutical organizations are proposed, divided into general responsibilities, responsibilities in the field of marketing, responsibilities in the field of procurement, responsibilities in the field of assortment, responsibilities in the field of pricing, responsibilities in the field of interactions with subordinates, responsibilities in the field of planning and reporting, responsibilities in the field of analysis of sales effectiveness by category of pharmaceutical products. The rights and responsibilities of a category manager for pharmaceutical organizations are studied and formulated. The category manager is guided by normative materials on the organization of trade; standard of work with suppliers of the pharmaceutical organization; 
the standard of merchandising of the pharmaceutical organization; standards and technical conditions for storage and transportation of inventory; reporting regulations for category managers of the pharmaceutical organization; methods of analysis of demand and activity of competitors; labor regulations; orders, instructions of the head of the pharmaceutical organization; job description.

Keywords: category manager, pharmaceutical organization, job responsibilities, drug, rights, responsibilities.

Постановка проблеми. Сучасний фармацевтичний ринок України характеризується широким асортиментом лікарських засобів. Так, станом на 14.03.2021 p. в Україні зареєстровано 10776 лікарських засобів, серед яких 3629 вітчизняних та 7147 іноземних препаратів [1]. Фармацевтичні компанії України виробляють лікарські засоби практично усіх лікарських форм (м'які, рідкі, тверді тощо) усіх фармакотерапевтичних груп (анальгетики, антибіотики, вітаміни, кишково-шлунковий тракт та обмін речовин, серцевосудинні препарати та ін.).

Слід зазначити, що фармацевтичний ринок $\epsilon$ динамічним, так, у 2019 р. обсяги роздрібної реалізації фармацевтичних товарів (лікарські засоби, медичні вироби, косметика, дієтичні добавки) збільшилися на 16,5\% порівняно з 2018 р. При цьому, спостерігалося скорочення обсягів продажу фармацевтичних товарів у натуральному вираженні на 2,8\% (рис. 1).

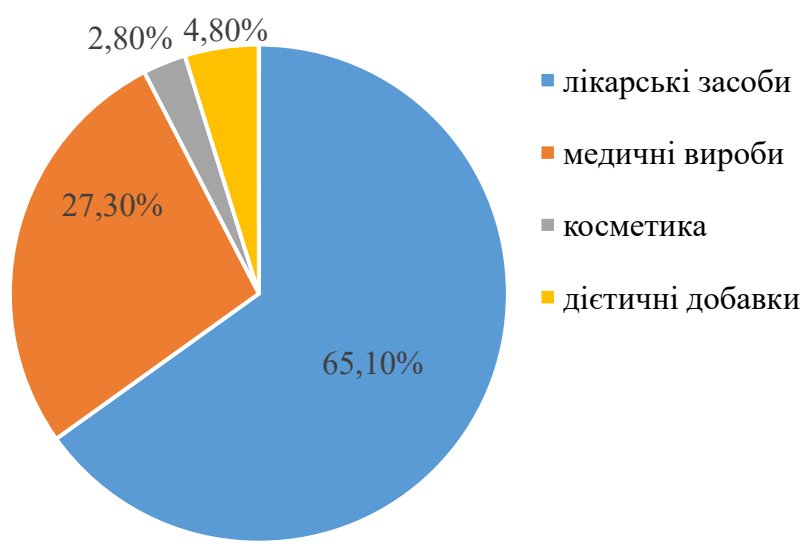

Рис. 1. Частка категорій фармацевтичних товарів в «аптечному кошику» України у 2019 р.

Значне зменшення обсягів продажів у натуральному вираженні спостерігається у лікарських засобів (на 2,8\%) та медичних виробів (на 5,3\%), а збільшення - у косметики (на $1,5 \%$ ) та дієтичних добавок (на 4,8\%) [1].

Аналіз останніх досліджень і публікацій. На сьогодні питанням категорійного менеджменту присвячено велику кількість публікацій, в основному стосовно управління товарними категоріями в роздрібній торгівлі, управління асортиментом категорій товарів, управління запасами та стратегії в категорійному менеджменті.

Виділення невирішених раніше частин загальної проблеми. Слід зазначити, що одним 3 завдань категорійного менеджемту, якому на сьогоднішній день не приділено значної уваги, $є$ формування уявлень про організаційні і управлінські функції, пов'язані з закупівлею, зберіганням і транспортуванням товарів.

Формулювання цілей статті. Метою статті $€$ визначення посадових обов'язків категорійних менеджерів з урахуванням специфіки фармацевтичних організацій і вимог, які висуваються до закупівлі, зберігання та транспортування фармацевтичної продукції.

Виклад основного матеріалу дослідження. Характерною рисою ринкової економіки $є$ насичення будь-якого ринку, зокрема і фармацевтичного, різноманітними товарами, що, з одного боку, підвищує рівень задоволеності споживачів, а, з іншого, створює значні труднощі для їх просування до кінцевого споживача. Крім того, насиченість ринку товарами спричиняє проблему вибору у споживачів, які не завжди можуть визначитися у виборі необхідного товару, що викликає необхідність формування оптимального асортименту, а відповідно і визначення нових підходів до управління ним 3 урахуванням інноваційних підходів. Слід зазначити, що такий підхід повинен базуватися на методології категорійного менеджменту. Це зумовило доцільність впровадження посади категорійного менеджера, тобто фахівця з управління асортиментів товарів.

Категорійні менеджери посідають важливе місце в каналі товароруху та займається управлінням асортиментом магазину з метою збільшення обсягів продажів фармацевтичної організації, бере участь в процесах закупівлі, зберігання, мерчендайзингу, стимулюванні збуту і реалізації продукції. 3 цієї причини йому потрібно знати маркетинг, мерчандайзинг, закупівлі, логістику, продажу та інші процеси торгівлі та економіки.

Завданням категорійного менеджера $\epsilon$ управління певного менеджеру категорією товарів. Для виконання своїх функцій категорійний менеджер формує замовлення на закупівлю товарів, за яку він несе відповідальність, управління присутністю категорії на складі фармацевтичної організації. Крім того, він повинен координувати й організовувати діяльність фахівців маркетингу (мерчандайзери, бренд-менеджери, торгові представники постачальників), постачальників та інших фахівців. Поряд 3 поточним і оперативним менеджментом, пов'язаних з контролем і оптимізацією товарні запасів, категорійний менеджер повинен розробляти стратегію розвитку своєї товарної категорії, плани оновлення категорії, стратегію постачання i реалізації товарів категорії. 
У своїй діяльності категорійний менеджер керується нормативними матеріалами з питань організації торгівлі; стандартом роботи з постачальниками фармацевтичної організації; стандартом мерчандайзингу фармацевтичної організації; стандартами i технічними умовами на зберігання й перевезення товарно-матеріальних цінностей; положенням про звітність для категорійних менеджерів фармацевтичної організації; методами аналізу попиту та діяльності конкурентів; правилами трудового розпорядку; наказами, розпорядженнями керівника фармацевтичної організації; посадовою інструкцією.

Функціональні обов'язки категорійного менеджера на підставі анкетування доцільно поділити за кластерами - загальні; ціноутворення; взаємодія з підлеглими; планування і звітність (табл. 1).

Категорійний менеджер має певні права та несе відповідальність (табл. 2).

Функціональні обов'язки категорійного менеджера

Таблиця 1

\begin{tabular}{|c|c|c|}
\hline $\begin{array}{l}\text { № } \\
\text { 3/II }\end{array}$ & Функціональні обов'язки & $\begin{array}{l}\text { Усереднений } \\
\text { ранг }\end{array}$ \\
\hline 1 & Загальні & \\
\hline 1.1 & $\begin{array}{l}\text { Виконує або стежить за виконанням розпоряджень і наказів керівництва, що стосуються роботи } \\
\text { торгового відділу, посаді категорійного менеджера або підлеглих працівників (експедиторів) }\end{array}$ & 95,4 \\
\hline 1.2 & $\begin{array}{l}\text { Доповідає керівництву про порушення в процесі товароруху і невиконання підлеглими } \\
\text { своїх посадових обов'язків }\end{array}$ & 91,2 \\
\hline 1.3 & Інформує керівництво про наявні недоліки в роботі фармацевтичної організації & 89,7 \\
\hline 1.4 & Забезпечує режим збереження комерційної таємниці фармацевтичної організації & 95,4 \\
\hline 1.5 & $\begin{array}{l}\text { Бере участь у розробці заходів з усунення негативних результатів інвентаризацій } \\
\text { (недостача, надлишки, пересортиця) }\end{array}$ & 78,2 \\
\hline 2 & Обов'язки у сфері маркетингу & \\
\hline 2.1 & Формує та узгоджує з керівником фармацевтичної організації асортиментні матриці & 62,6 \\
\hline 2.2 & Формує та узгоджує з керівником пропозиції про зміни в асортиментної матриці & 65,9 \\
\hline 2.3 & Організація просування фармацевтичних товарів на ринку & 78,1 \\
\hline 2.4 & Розробка маркетингових заходів з підтримки і стимулювання продажу фармацевтичних товарів & 73,2 \\
\hline 2.5 & Формує та затверджує з керівником пропозиції про оновлення категорій фармацевтичних товарів & 66,8 \\
\hline 3 & Обов'язки у сфері закупівлі & \\
\hline 3.1 & Здійснює пошук постачальників фармацевтичних товарів & 98,4 \\
\hline 3.2 & $\begin{array}{l}\text { Організовує роботу з постачальниками згідно зі стандартними операційними процедурами } \\
\text { роботи з постачальниками фармацевтичної організації }\end{array}$ & 96,5 \\
\hline 3.3 & $\begin{array}{l}\text { Організовує своєчасне укладання договорів з постачальниками фармацевтичних товарів та } \\
\text { контролює виконання їх договірних зобов'язань }\end{array}$ & 95,7 \\
\hline 3.4 & Формує замовлення фармацевтичних товарів & 95,4 \\
\hline 3.5 & Контролює своєчасне надходження замовлених товарів фармацевтичну організацію & 91,3 \\
\hline 3.6 & $\begin{array}{l}\text { Формує та затверджує з керівництвом пропозиції про зміну постачальника чи припинення } \\
\text { роботи з постачальником }\end{array}$ & 91,2 \\
\hline 4 & Обов'язки у сфері асортименту & \\
\hline 4.1 & Контролює наявність повного асортименту товарів в фармацевтичній організації & 93,9 \\
\hline 4.2 & Контролює товарні залишки товарів фармацевтичної організації & 90,2 \\
\hline 5 & Обов'язки у сфері иіноутворення & \\
\hline 5.1 & $\begin{array}{l}\text { Формує та затверджує з керівництво пропозиції про величину націнки на окремі види } \\
\text { фармацевтичних товарів }\end{array}$ & 86,5 \\
\hline 5.2 & $\begin{array}{l}\text { Формує та затверджує з керівництво пропозиції про зміну роздрібних цін (переоцінці) } \\
\text { фармацевтичних товарів }\end{array}$ & 83,9 \\
\hline 5.3 & Участь у розробці та реалізації цінової стратегії & 80,1 \\
\hline 5.4 & Участь у формуванні прайс-листів & 75,6 \\
\hline 6 & Обов'язки у сфері взаємодї̈ з підлеглими & \\
\hline 6.1 & $\begin{array}{l}\text { Контролює виконання функціональних обов'язків експедиторів відповідно до вимог їх } \\
\text { посадової інструкції }\end{array}$ & 67,7 \\
\hline 6.2 & $\begin{array}{l}\text { Організовує та контролює поточну роботу експедиторів відповідно до вимог організації } \\
\text { товароруху з урахуванням стану справ в фармацевтичній організації }\end{array}$ & 64,6 \\
\hline 7 & Обов'язки у сфері планування і звітності & \\
\hline 7.1 & $\begin{array}{l}\text { Аналізує роботу наявних і потенційних постачальників відповідно до вимог, які } \\
\text { висуваються до постачальників }\end{array}$ & 74,2 \\
\hline
\end{tabular}


(Закінчення таблиці 1)

\begin{tabular}{|c|c|c|}
\hline $\begin{array}{l}\text { № } \\
\text { 3/II }\end{array}$ & Функціональні обов’язки & \begin{tabular}{|c|} 
Усереднений \\
ранг
\end{tabular} \\
\hline 7.2 & Аналізує попит і пропозицій партнерів фармацевтичної організації & 69,3 \\
\hline 7.3 & $\begin{array}{l}\text { Бере участь спільно з керівником фармацевтичної організації в плануванні показників } 3 \\
\text { продажу фармацевтичних товарів }\end{array}$ & 59,2 \\
\hline 7.4 & $\begin{array}{l}\text { Аналізує діяльність конкурентів відповідно до методів аналізу, прийнятих в } \\
\text { фармацевтичній організації }\end{array}$ & 55,7 \\
\hline 7.5 & $\begin{array}{l}\text { Аналізує продажу фармацевтичних товарів відповідно до методів аналізу, прийнятих в } \\
\text { фармацевтичній організації }\end{array}$ & 54,8 \\
\hline 7.6 & $\begin{array}{l}\text { Надає звіти за результатами аналізу продажу товарів у встановлені терміни за } \\
\text { встановленими формами }\end{array}$ & 52,3 \\
\hline 7.7 & На підставі результатів планує подальшу роботу фармацевтичних товарів & 51,8 \\
\hline 8 & Обов 'язки у сфері аналізу ефективності продажів по категоріях фармацевтичних товарів & \\
\hline 8.1 & $\begin{array}{l}\text { Складання порівняльних аналізів (ABC, XYZ, поєднаний аналіз) за категоріями } \\
\text { фармацевтичних товарів }\end{array}$ & 97,8 \\
\hline 8.2 & Аналіз ліквідності товарів і підтримання рівня оборотності & 96,3 \\
\hline 8.3 & Аналіз продажів і прибутковості окремих фармацевтичних товарів і категорії в цілому & 95,9 \\
\hline 8.4 & Аналіз задоволеності покупців & 92,1 \\
\hline
\end{tabular}

Таблиця 2

Права та відповідальність категорійного менеджера

\begin{tabular}{|l|l|}
\hline \multicolumn{1}{|c|}{ Права } & \multicolumn{1}{|c|}{ Відповідальність } \\
\hline - приймати рішення в межах функціональних обов'язків; & - за неналежне виконання або невиконання \\
- знайомитися з проєктами рішень керівництва & посадових обов'язків, передбачених цією \\
фармацевтичної організації стосовно питань та входять & посадовою інструкцією, в межах, визначених \\
в його компетенцію; & чинним законодавством України про працю; \\
- виносити на розгляд керівництва пропозиції & -за неналежне виконання підлеглими посадових \\
щодо поліпшення торгового процесу і діяльності & обов'язків, передбачених відповідними посадовими \\
фармацевтичної організації; & інструкціями, в межах, визначених чинним \\
- виявляти недоліки в роботі фармацевтичної організації, & законодавством України про працю; \\
виявлених у процесі виконання посадових обов'язків & - за завдання матеріальної шкоди в межах, \\
та виносити пропозиції щодо їх усунення. & визначених чинним трудовим і цивільним \\
- запитувати особисто або за дорученням & законодавством; \\
безпосереднього керівника інформацію та документи, & - за помилки, допущені в процесі виконання \\
необхідні для виконання посадових обов'язків; & своїх безпосередніх посадових обов'язків, \\
- вимагати виконання встановлених правил роботи & в межах, визначених чинним трудовим \\
з документами; & і цивільним законодавством; \\
- отримувати від керівництва інформацію і документи, & - за розголошення інформації, що є комерційною \\
необхідні для виконання посадових обов'язків; & таємницею, в межах, визначених чинним трудовим \\
- вимагати від керівництва фармацевтичної організації & і цивільним законодавством \\
сприяння у виконанні посадових обов'язків і прав & \\
\hline
\end{tabular}

Впровадження посади категорійного менеджера дозволяє збільшити обсяги продажів товарів та рівень задоволеності партнерів.

Висновки. Досліджено стан фармацевтичного ринку України. Сформовано особливості фармацевтичного ринку України. Визначено характерні риси ринкової економіки. Визначено доцільність впровадження посади категорійного менеджеру для фармацевтичних організацій. Сформовано завдання, права, відповідальність та функціональні обов'язки категорійного менеджера, які враховують специфіку фармацевтичних організацій.

\section{Список використаних джерел:}

1.Державна служба статистики України. URL: http://www.ukrstat.gov.ua/

2. Буянова Е., Давыдов Н. Категорийный менеджмент. Теория и практика в России. Москва : ECR-RYS, 2008. 47 c.

3. Голова А. Г. Управление продажами : учебник. Москва : Дашков и К, 2015, 280 с.

4. Должанский И. 3., Лозюк В. Н. Управление ассортиментом торгового предприятия на основе портфельной теории. Ефективна економіка. 2010. № 10. URL: http://www.economy.nayka.com.ua/?op=1\&z=347

5.Йенс Нордфальт. Ритейл-маркетинг: Практики и исследования. Москва : Альпина Паблишер, 2015. 490 с.

6. Киселев К. М., Николаева М. А. Категорийный менеджмент. Москва : Норма : ИНФРА-М, 2013. 208 с. 
7.Киселев В. М. Методология управления ассортиментом товаров в интегрированных торговых каналах. Управление каналами дистрибуциии. 2006. № 2. С. 120-130.

8. Киселев В. М. Теоретические и практические аспекты формирования ассортимента товаров. Современные приоритеты питания, пищевой промышленности и торговли. 2006. С. 219-224.

9. Киселев В. М., Мазанько Е. И. Управление ассортиментом товаров. Москва-Кемерово : Объединенное издательство «Российские университеты», 2006. 206 с.

10.Магомедов Ш. Ш. Управление товарным ассортиментом и запасами: учебник для бакалавров. Москва : Издательство «Дашков и К», 2016. 176 с.

11. Сысоева С. В. Стандарт розничного предприятия. Разработка инструкций и регламентов. Санкт-Петербург : Питер, 2007. 368 с.

12.Сысоева С. В., Бузукова Е. А. Управление ассортиментом в рознице. Категорийный менеджмент. СанктПетербург : Питер, 2011. 288 с.

13.Управление ассортиментом и качеством товаров и услуг : учебное пособие / сост. Э. Н. Разнодежина. Ульяновск : УлГТУ, 2016. 112 с.

14. Чувакова С. Г. Управление ассортиментом магазина : практ. пособие. Москва : Дашков и Ко, 2012.260 с.

\section{References:}

1.Derzhavna sluzhba statistiki Ukrayini. UKR: http://www.ukrstat.gov.ua/

2. Buyanova E., Davy`dov N. (2008). Kategorijny`j menedzhment. Teoriya i praktika v Rossii. Moscow: ESR-RYS, 47.

3. Golova A. G. (2015). Upravlenie prodazhami: uchebnik. Moscow: Dashkov i K, 280.

4. Dolzhanskij I. Z., Lozyuk V. N. (2010). Upravlenie assortimentom torgovogo predpriyatiya na osnove portfelnoj teorii. Efektivna ekonomika, 10. URL: http:/www.economy.nayka.com.ua/?op=1\&z=347

5. Jens Nordfalt (2015). Ritejl-marketing: Praktiki i issledovaniya. Moscow: Alpina Pablisher, 490.

6. Kiselev K. M., Nikolaeva M. A. (2013). Kategorijny`j menedzhment. Moscow: Norma: INFRA-M, 208.

7. Kiselev V. M. (2006). Metodologiya upravleniya assortimentom tovarov v integrirovannykh torgovykh kanalakh. Upravlenie kanalami distribuczii, 2, 120-130.

8. Kiselev V. M. (2006). Teoreticheskie i prakticheskie aspekty` formirovaniya assortimenta tovarov. Sovremenny ’e prioritety 'pitaniya, pishhevoj promy shlennosti i torgovli, 219-224.

9. Kiselev V. M., Mazanko E. I. (2006). Upravlenie assortimentom tovarov. Moscow-Kemerovo: Obedinennoe izdatelstvo «Rossijskie universitety», 206.

10. Magomedov Sh. Sh. (2016). Upravlenie tovarnym assortimentom i zapasami: uchebnik dlya bakalavrov. Moscow: Izdatelstvo «Dashkov i K», 176.

11. Sysoeva S. V. (2007). Standart roznichnogo predpriyatiya. Razrabotka instrukczij i reglamentov. Sankt-Peterburg: Piter, 368.

12.Sysoeva S. V., Buzukova E. A. (2011). Upravlenie assortimentom v roznicze. Kategorijnyj menedzhment. Sankt-Peterburg: Piter, 288.

13. Upravlenie assortimentom i kachestvom tovarov i uslug: uchebnoe posobie / sost. E. N. Raznodezhina. Ul yanovsk: UlGTU, 2016, 112.

14.Chuvakova S. G. (2012). Upravlenie assortimentom magazina: prakt. posobie. Moscow: Dashkov i Ko, 260. 